\title{
Elevated Stream Pathogenic Indicator Bacteria Concentrations in Livestock Grazing Areas across a Single National Forest
}

\author{
Lindsey Myers, Megan Fiske, Megan Layhee* \\ Central Sierra Environmental Resource Center, Twain Harte, CA, USA \\ Email: *megl@cserc.org
}

How to cite this paper: Myers, L., Fiske, M. and Layhee, M. (2017) Elevated Stream Pathogenic Indicator Bacteria Concentrations in Livestock Grazing Areas across a Single National Forest. Natural Resources, 8, 657-670.

https://doi.org/10.4236/nr.2017.810042

Received: September 30, 2017

Accepted: October 28, 2017

Published: October 31, 2017

Copyright $(9) 2017$ by authors and Scientific Research Publishing Inc. This work is licensed under the Creative Commons Attribution International License (CC BY 4.0).

http://creativecommons.org/licenses/by/4.0/

\begin{abstract}
Livestock presence in proximity to forest streams has been shown to contribute pathogenic bacteria in excess of water quality standards established to protect human health. However, the degree to which livestock fecal contamination in streams on national forest lands is either a limited or a potentially widespread occurrence is still debated. This study provides additional insight into the matter. We analyzed water in small streams near known cattle grazing areas within the Stanislaus National Forest in the Sierra Nevada, California from 2012 to 2016. Fourteen stream sites were sampled before and after cattle were released onto the forest (four of these sites were sampled across multiple years) to compare indicator bacteria concentrations (fecal coliform-FC, Escherichia coli-EC) to standards established for recreational contact for surface waters. One control site was also sampled. There were 194 water quality violations of either state or federal regulatory standards for recreational contact, all of which occurred once cattle were on the forest. Mean $(\max )$ FC and EC concentrations were on orders of magnitude higher after cattle were released onto the forest [FC $1307(30,000)$ and EC $1033(17,000) \mathrm{MPN} / 100 \mathrm{~mL}$ ] than during the time period before cattle were on the forest [FC 19 (220) and EC 17 (220) MPN/100 mL; FC, $\mathrm{F}_{1,210}=105, \mathrm{p}<$ $\left.0.001 ; \mathrm{EC}, \mathrm{F}_{1,210}=85.5, \mathrm{p}<0.001\right]$. In addition, the presence of cattle, visual evidence of recent cattle-related disturbances, and sampling week were important predictor variables of FC and EC. These findings support the link between cattle presence and increased levels of stream pathogenic bacteria, and also demonstrate that stream pathogenic bacteria pollution occurs widely across the forest. This research indicates the need to consider alternative range management practices to better protect water quality and human health.
\end{abstract}




\section{Keywords}

Cattle, Escherichia coli, Fecal Coliform, Sierra Nevada, Water Quality

\section{Introduction}

National forests in the United States are managed for diverse and often competing purposes such as providing habitat for wildlife and water supplies for downstream urban users, while also managing for wood production, livestock grazing, and recreation. In California alone, national forest lands receive more than 33 million recreational visits each year [1]. For over a century, a substantial percentage of those heavily visited national forestlands have also been utilized for livestock grazing. Of the nearly 21 million acres of national forest land in US Forest Service (USFS) Region 5 within California [1], livestock grazing is permitted on over half of those lands(over 12 million acres) [2]. Research has demonstrated that livestock activities near aquatic habitat have the potential to diminish water quality, lead to soil compaction, cause stream channel erosion, and alter vegetative structure, as summarized in several reviews including [3] [4] [5]. Such impacts can affect recreational use and also create potential for the risk of human illness through bodily contact with contaminated water or ingestion of polluted water. Recreational use on national forest lands is projected to rise [6], increasing the need for land managers and the public to understand the extent of water quality pollution on forest lands, and the relationship between livestock grazing on national forest lands and pathogenic bacteria pollution.

Cattle disproportionately use national forest aquatic areas over non-aquatic forest areas because these habitats provide ample water and forage. Cattle presence in riparian areas or wet meadow habitats not only can affect vulnerable resources, but can also result in pathogenic organisms (e.g., bacteria, viruses), nutrients (e.g., nitrogen, phosphorus) and other organic matter to be discharged into water bodies through both direct and non-direct inputs (overland transport) of manure and urine [4] [5]. All of these effects can degrade water quality that is important for humans and wildlife [7]. State and federal water quality standards have been established for the protection of recreational users against contracting illness from ingestion of polluted water or from bodily contact with fecal contaminated water. Pathogenic indicator bacteria (e.g., fecal coliform, Escherichia coli) in water samples are indicators of fecal contamination and are used as surrogates for the presence of pathogenic organisms (e.g., Cryptosporidium, Giardia, E. coli 0157: H7) in state and federal water quality standards. Although the specific pathogenic indicator bacteria and the threshold levels for a particular indicator bacteria used for recreational water contact standards vary between state and federal agencies and vary within individual states, these standards are all intended to protect recreational users against contracting illness from contact with contaminated water [7] [8] [9].

There is a growing body of literature suggesting that elevated levels of patho- 
genic indicator bacteria concentrations in surface waters are strongly associated with cattle presence [10]-[18]. In contrast, one study [19] provided unclear conclusions regarding stream bacteria pollution and suggested that the extent of livestock contributions to pathogenic bacteria in forest streams is minimal. In their study [19] they did find that pathogenic indicator bacteria levels (both fecal coliform and $E$. coli) were significantly higher when cattle were present during sampling. Their paper also acknowledged that up to $82 \%$ of their study's stream sites (depending on which California Region water quality standard was applied) within grazing areas had violations of fecal coliform (California standards), rather than the E. coli (federal standards) [19]. Two other studies that looked at cattle impacts to river and forest wetl and habitats concluded that cattle had minimal effects on water quality and habitat conditions; however, these studies did not actually assess fecal contamination [20] [21]. Thus, for studies that did assessfecal contamination in streams associated with livestock presence, there is consistent evidence that cattle presence is associated with diminished stream water quality. A key question, however, is the degree to which livestock fecal contamination in streams is either limited or is potentially widespread when cattle graze across significant areas of national forest land. This study provides data that helps to answer that question.

The objective of this study was to assess pathogenic indicator bacteria concentrations (fecal coliform and E. coli) in streams within grazing areas in a single national forest sampled within a five-year period. Specifically, the study aimed to determine (1) the number of pathogenic indicator bacteria violations of state (fecal coliform) and federal (E. coli) regulatory standards for recreational water contact in forest streams; and (2) if pathogenic indicator bacteria concentrations were related to the presence of cattle on the forest and/or evidence of recent cattle-related disturbances (e.g., manure or other evidence that cattle had been in the area recently). Building upon past studies [16] [17], this study hypothesizes that fecal coliform and E. coli concentrations will be related to the presence of cattle as well as evidence of recent cattle-related disturbances, and that pathogenic bacteria concentrations will at times result in violations of state and federal regulatory standards when cattle are present.

\section{Materials and Methods}

\subsection{Study Location}

This study occurred exclusively within the Stanislaus National Forest (STF) located on the western slope of the central Sierra Nevada, California. The STF encompasses 898,000 acres and 800 miles of rivers and streams [22]. Seventy percent of lands on the STF (634,000 acres) are available for livestock within 36 grazing allotments [2]. In this study small perennial streams within three watersheds (the Mokelumne, Stanislaus, and Tuolumne Rivers) were sampled within 6 of the 36 allotments including Bell Meadow-Bear Lake, Long Valley-Eagle Meadow, Herring Creek, Highland Lakes, Rushing, and Upper Hull Allotment on the STF from 2012 through 2016 (Figure 1). See Table 1 and Table 2 for specific 
Table 1. Mean fecal coliform (FC) and Escherichia coli (EC) concentrations (MPN/100 mL) before cattle were on the forest ("before") and after cattle were released onto the forest ("after") for 14 stream sites and one control site during initial sampling years on the Stanislaus National Forest, CA. Number of state (California Regional Water Quality Control Board Central Valley Region 5 Basin Plan) [8] or federal (US Environmental Protection Agency) [7] [9] water quality violations for recreational water contact standards is also shown for each site.

\begin{tabular}{|c|c|c|c|c|c|c|c|c|c|c|c|}
\hline \multirow[b]{2}{*}{ Stream (abbrev.) } & \multirow[b]{2}{*}{$\begin{array}{l}\text { Grazing } \\
\text { Allotment }\end{array}$} & \multirow[b]{2}{*}{$\begin{array}{l}\text { Coordinates } \\
\text { (NAD83) }\end{array}$} & \multirow[b]{2}{*}{$\begin{array}{l}\text { Elev. } \\
(\mathrm{m})\end{array}$} & \multirow[b]{2}{*}{ Year } & \multicolumn{3}{|c|}{ Cattle on forest } & \multicolumn{4}{|c|}{ Number of violations } \\
\hline & & & & & $\begin{array}{l}\text { No. of } \\
\text { sample }\end{array}$ & $\begin{array}{l}\text { "Before" } \\
\text { FC, EC }\end{array}$ & $\begin{array}{l}\text { "After" } \\
\text { FC, EC }\end{array}$ & $\mathrm{CA}^{\mathrm{a}, \mathrm{b}}$ & $\begin{array}{c}\text { EPA } \\
1986^{c, d}\end{array}$ & $\begin{array}{c}\text { EPA } \\
2012^{\mathrm{e}, \mathrm{f}}\end{array}$ & $\begin{array}{c}\text { EPA } \\
2012^{g, h}\end{array}$ \\
\hline Bell Creek (BC_MBM) & $\begin{array}{c}\text { Bell Meadow-Bear } \\
\text { Lake }\end{array}$ & $38.1652,-119.9413$ & 1991 & 2015 & 15 & 2,2 & $\begin{array}{l}7,753 \\
6,824\end{array}$ & 20 & 20 & 20 & 20 \\
\hline $\begin{array}{c}\text { Bourland Creek } \\
\text { (BOUC_BOM) control site }\end{array}$ & Upper Hull & $38.1092,-119.9124$ & 2225 & 2012 & 3 & -- & $\begin{array}{c}2,2 \\
\text { (no cows) }\end{array}$ & 0 & 0 & 0 & 0 \\
\hline Cow Creek (CC_BR) & Herring Creek & $38.2492,-119.9637$ & 2022 & 2012 & 5 & 37,17 & 75,50 & 0 & 0 & 0 & 0 \\
\hline Eagle Creek (EC_EM) & $\begin{array}{c}\text { Long Valley-Eagle } \\
\text { Meadow }\end{array}$ & $38.2887,-119.8346$ & 2287 & 2015 & 6 & 2,2 & 31,27 & 0 & 0 & 0 & 0 \\
\hline Herring Creek (HerC_HC) & Herring Creek & $38.2621,-119.9115$ & 2318 & 2014 & 12 & 2,2 & 4,3 & 0 & 0 & 0 & 0 \\
\hline $\begin{array}{l}\text { Niagara Creek Upper } \\
\text { (NC_BM_U) }\end{array}$ & $\begin{array}{c}\text { Long Valley-Eagle } \\
\text { Meadow }\end{array}$ & $38.2884,-119.8601$ & 2303 & 2016 & 11 & 2,2 & 111,50 & 1 & 0 & 0 & 0 \\
\hline $\begin{array}{l}\text { Niagara Creek Lower } \\
\quad(\text { NC_EMR_L) }\end{array}$ & $\begin{array}{c}\text { Long Valley-Eagle } \\
\text { Meadow }\end{array}$ & $38.3007,-119.8763$ & 2179 & 2014 & 8 & 2,2 & 114,114 & 0 & 1 & 0 & 0 \\
\hline $\begin{array}{l}\text { NF Mokelumne River } \\
\text { (NFMOKE_BCG) }\end{array}$ & Highland Lakes & $38.5344,-119.8199$ & 2392 & 2012 & 7 & 2,2 & 20,19 & 0 & 0 & 0 & 0 \\
\hline Rose Creek (RC) & Rushing & $38.1417,-120.1999$ & 1145 & 2015 & 21 & 5,5 & 453,396 & 4 & 6 & 2 & 2 \\
\hline Trib. Bell Creek (TBC_LRM) & $\begin{array}{c}\text { Bell Meadow-Bear } \\
\text { Lake }\end{array}$ & $38.1580,-119.9569$ & 1932 & 2012 & 12 & 74,74 & 421,397 & 4 & 5 & 4 & 4 \\
\hline $\begin{array}{l}\text { Trib. Elbow Creek Lower } \\
\text { (TEC_SM_L) }\end{array}$ & Highland Lakes & $38.5622,-119.8589$ & 2634 & 2012 & 8 & 2,2 & 288,288 & 1 & 3 & 2 & 2 \\
\hline $\begin{array}{l}\text { Trib. Elbow Creek Upper } \\
\text { (TEC_SM_U) }\end{array}$ & Highland Lakes & $38.5624,-119.8588$ & 2640 & 2012 & 8 & 2,2 & $\begin{array}{c}1,057 \\
774\end{array}$ & 2 & 4 & 2 & 2 \\
\hline $\begin{array}{l}\text { Trib. Herring Creek } \\
\text { (THERC_UFG) }\end{array}$ & Herring Creek & $38.2242,-119.9685$ & 1966 & 2012 & 6 & 51,34 & 127,109 & 0 & 1 & 0 & 0 \\
\hline $\begin{array}{l}\text { Trib. } 1 \text { NF Mokelumne River } \\
\text { (TNFMOKE_BCG) }\end{array}$ & Highland Lakes & $38.5340,-119.8197$ & 2399 & 2012 & 10 & 2,2 & 418,417 & 2 & 2 & 2 & 2 \\
\hline \multirow[t]{2}{*}{$\begin{array}{l}\text { Trib. } 2 \text { NF Mokelumne River } \\
\text { (TNFMOKE_BTM) }\end{array}$} & Highland Lakes & $38.501,-119.7889$ & 2548 & 2014 & 11 & 2,2 & 21,20 & 0 & 0 & 0 & 0 \\
\hline & & Total violations & & & & & & 34 & 42 & 32 & 32 \\
\hline
\end{tabular}

-, no data. (a) State recreational water contact threshold for fecal coliform (FC) is at least 5 samples within a given 30-day period during which a geometric mean of $200 \mathrm{cfu} / 100 \mathrm{~mL}$ cannot be exceeded [8]. (b) State recreational water contact threshold for fecal coliform (FC) is at least 5 samples within a given 30 -day period during which no more than $10 \%$ of samples may exceed $400 \mathrm{cfu} / 100 \mathrm{~mL}$ [8]. (c) Federal recreational water contact threshold for E. coli (EC) is at least 5 samples within a given 30-day period during which a geometric mean of $126 \mathrm{cfu} / 100 \mathrm{~mL}$ cannot be exceeded [9]. (d) Federal recreational water contact threshold for $E$. coli $(\mathrm{EC})$ is at least 5 samples within a given 30 -day period during which no more than $10 \%$ of samples may exceed $235 \mathrm{cfu} / 100 \mathrm{~mL}$ [9]. (e) Federal recreational water contact threshold for E. coli (EC) is at least 5 samples within a given 30 -day period during which a geometric mean of 126 $\mathrm{cfu} / 100 \mathrm{~mL}$ cannot be exceeded [7]. (f) Federal recreational water contact threshold for E. coli (EC) is at least 5 samples within a given 30 -day period during which no more than $10 \%$ of samples may exceed $410 \mathrm{cfu} / 100 \mathrm{~mL}$ [7]. (g) Federal recreational water contact threshold for E. coli (EC) is at least $5 \mathrm{samples}$ within a given 30-day period during which a geometric mean of $126 \mathrm{cfu} / 100 \mathrm{~mL}$ cannot be exceeded [7]. (h) Federal recreational water contact threshold for E. coli (EC) is at least 5 samples within a given 30 -day period during which no more than $10 \%$ of samples may exceed $310 \mathrm{cfu} / 100 \mathrm{~mL}$ [7].

stream site locations.

\subsection{Stream Site Selection}

Sample sites were located at 14 stream locations at elevations of 1145 - $2640 \mathrm{~m}$. Sites were sampled two to four weeks before cattle were released onto the forest, starting in April, May or June (depending on when cattle are released onto the 

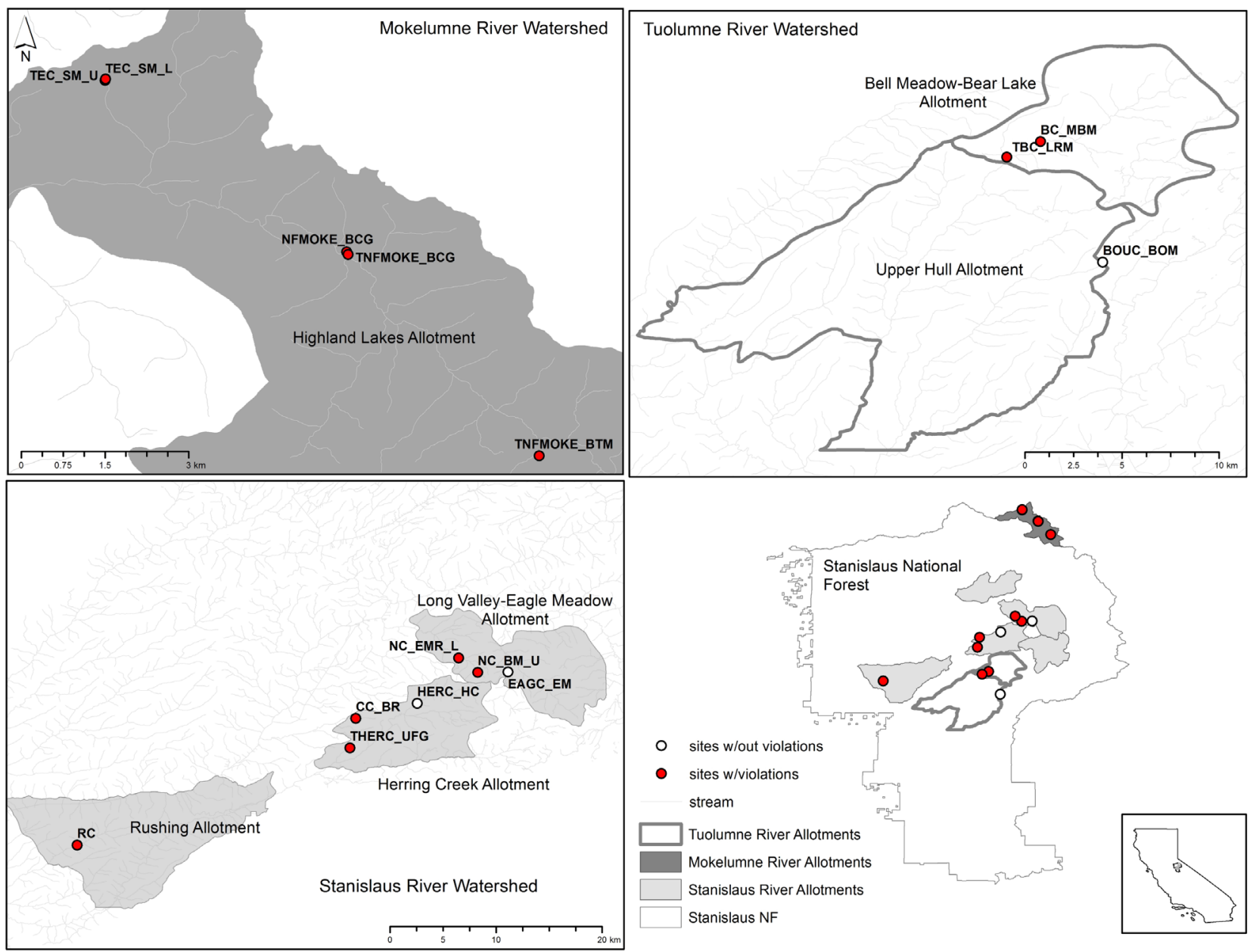

Figure 1. Map of study sites in six grazing allotments within the Mokelumne, Stanislaus, and Tuolumne River watersheds of the Stanislaus Nation Forest, CA. Red dots indicate sites that had at least one violation of state [8] or federal [7] [9] standards for recreational water contact between 2012 and 2016. White dots are for sites that had no violations.

forest, elevation, timing of snowmelt runoff, and accessibility). After cattle were released onto the forest, sites were sampled for up to 11 weeks. Sites were selected based on there being known grazing areas upstream of or adjacent the selected forest streamsites. Four of the 14 sites were sampled across multiple years.

A control site was also sampled, located on Bourland Creek (2225 m, elevation) within the Bourland Research Natural Area in the Upper Hull Allotment. No livestock grazing is authorized with the Bourland Research Natural Area. Wire fencing is used to exclude this area from livestock use during the summer grazing season. Bourland Creek was sampled in 2012 and also in 2013. However, in that year cattle trespassed into the Bourland Research Natural Area upstream of the sampling site, so the site was not utilized as a control site in 2013, and data from 2013 was omitted from analyses.

\subsection{Field Collection and Laboratory Procedures}

Stream water sampling procedures and quality assurance measures followed a 
Quality Assurance Project Plan (QAPP) developed with State Water Resources Control Board [23] [24]. Sterile bottles were used to collect $100 \mathrm{~mL}$ of water within the stream thalweg approximately $10 \mathrm{~cm}$ below the stream surface. When multiple water samples were collected within an individual site visit, samples were collected five minutes apart. Sample bottles were stored on ice in plastic bags.

During each sampling event, observational data was collected pertaining to: 1) elevation, 2) coordinates (NAD83), 3) weather, 4) relative stream flow (high, high-medium, medium, medium-low, low, low-very low, or very low), 5) water sample color (none, amber, yellow, green, brown, gray), 6) water sampled odor (none, algae smell, chlorine, sulfide, sewage), 7) presence/absence of stream algae or aquatic plants, 8) presence/absence of cattle in the vicinity of the sample site at the time of sampling, and 9) presence/absence of visually discernable recent cattle-related disturbances (e.g., manure, pocking, sloughing, chiseling) in and along the stream site.

Laboratory procedures followed methods described in [16] [17]. Samples were delivered to a state-certified independent laboratory (AquaLab, Twain Harte, CA) within six hours of collection to determine concentrations of fecal coliform and $E$. coli as the most probable number (MPN) per $100 \mathrm{~mL}$ of water using multiple tube fermentation procedures [25]. The laboratories minimum detection limit for analyses was $2 \mathrm{MPN} / 100 \mathrm{~mL}$. The laboratories maximum detection limit was $1600 \mathrm{MPN} / 100 \mathrm{~mL}$, unless the laboratory was instructed to increase the detection limit.

\subsection{Data Interpretation and Analysis}

Bacterial concentrations for the 14 sites across the study period were summarized and compared to state (California Regional Water Quality Control Board Central Valley Region 5, CRWQCB Basin Plan) [8] and federal (US Environmental Protection Agency, EPA) recreational water contact criteria for fecal coliform and E. coli [7] [9]. Recreational water contact threshold for fecal coliform in freshwater is for at least five samples to be taken within a given 30-day period during which a geometric mean of $200 \mathrm{cfu} / 100 \mathrm{~mL}$ cannot be exceeded, and no more than $10 \%$ of samples may exceed $400 \mathrm{cfu} / 100 \mathrm{~mL}$ [8]. Standards for E. coli in freshwater for at least five samples within a given 30-day period includes a geometric mean that cannot exceed $126 \mathrm{cfu} / 100 \mathrm{~mL}$ or a single sample may not exceed $235 \mathrm{cfu} / 100 \mathrm{~mL}$ [9]. More current USEPA recommendations for recreational water contact for at least five samples within a given 30-day period include a geometric mean not to exceed $126 \mathrm{cfu} / 100 \mathrm{~mL}$ and standard threshold value of $410 \mathrm{cfu} / 100 \mathrm{~mL}$ for 36 per 1000 illness rate, or a geometric mean not to exceed $100 \mathrm{cfu} / 100 \mathrm{~mL}$ and standard threshold value of $320 \mathrm{cfu} / 100 \mathrm{~mL}$ for 32 per 1000 illness rate [7].

Analysis of variance (AOV) was used to evaluate the relationship between the presence of cattle, recent cattle-related disturbance (e.g., cattle manure, stream- 
bank pocking or chiseling), and sampling week (number of weeks since cattle were released onto the forest) with concentrations of fecal coliform and E. coli (response variables). drop1 function was used after running AOVs to evaluate the strength of different models based on the AIC criterion. AOVs were conducted in Rstudio (v. 0.99.903, Rstudio, Inc.) using the aovfunction. Correlation among predictor variables was assessed using rcorrfunction in Hmiscpackage. Highly correlated variables were excluded from models. Response variables were $\log$ transformed. Figure 2 was generated using ggplot 2 package.

\section{Results}

There were a total of 140 violations of either state or federal standards for recreational water contact at eight of the 14 grazing sites during initial sampling years, all of which occurred during the time that cattle were on the forest (Table 1). Three of the four sites sampled across multiple years had violations in subsequent sampling years, totaling 54 additional violations, all of which occurred once cattle were on the forest (Table 2). All violations of recreational water contact standards occurred within the first 5 weeks cattle were moved onto the forest, with the exception of violations measured at Bell Cr. These violations

Table 2. Mean fecal coliform (FC) and Escherichia coli (EC) concentrations (MPN/100 mL) before cattle were on the forest ("before") and after cattle were released onto the forest ("after") for four of the 15 stream sites that were sampled in subsequent years on the Stanislaus National Forest, CA. Number of state (California Regional Water Quality Control Board Central Valley Region 5 Basin Plan) [8] or federal (US Environmental Protection Agency) [9] [7] water quality violations for recreational water contact standards is also shown for each site.

\begin{tabular}{|c|c|c|c|c|c|c|c|c|c|c|c|}
\hline \multirow[b]{2}{*}{ Stream site } & \multirow[b]{2}{*}{$\begin{array}{l}\text { Grazing } \\
\text { Allotment }\end{array}$} & \multirow[b]{2}{*}{$\begin{array}{l}\text { Coordinates } \\
\text { (NAD83) }\end{array}$} & \multirow[b]{2}{*}{$\begin{array}{l}\text { Elev. } \\
(\mathrm{m})\end{array}$} & \multirow[b]{2}{*}{ Year } & \multirow[b]{2}{*}{$\begin{array}{l}\text { No. of } \\
\text { sample }\end{array}$} & \multicolumn{2}{|c|}{ Cattle on forest } & \multicolumn{4}{|c|}{ Number of violations } \\
\hline & & & & & & $\begin{array}{l}\text { "Before" } \\
\text { FC, EC }\end{array}$ & $\begin{array}{l}\text { “After" } \\
\text { FC, EC }\end{array}$ & $\mathrm{CA}^{\mathrm{a}, \mathrm{b}}$ & $\begin{array}{c}\text { EPA } \\
1986^{\mathrm{c}, \mathrm{d}}\end{array}$ & $\begin{array}{c}\text { EPA } \\
2012^{\mathrm{e}, \mathrm{f}}\end{array}$ & $\begin{array}{c}\text { EPA } \\
2012^{\text {g,h }}\end{array}$ \\
\hline Bell Creek (BC_MBM) & $\begin{array}{c}\text { Bell } \\
\text { Meadow-Bear Lake }\end{array}$ & $38.1652,-119.9413$ & 1991 & 2016 & 24 & 2,2 & $\begin{array}{l}4483 \\
2844\end{array}$ & 11 & 11 & 11 & 11 \\
\hline Cow Creek (CC_BR) & Herring Creek & $38.2492,-119.9637$ & 2022 & 2014 & 16 & 22,16 & 63,49 & 0 & 0 & 0 & 0 \\
\hline Cow Creek (CC_BR) & Herring Creek & $38.2492,-119.9637$ & 2022 & 2015 & 11 & 100,79 & 59,49 & 0 & 0 & 0 & 0 \\
\hline Cow Creek (CC_BR) & Herring Creek & $38.2492,-119.9637$ & 2022 & 2016 & 14 & 16,16 & 124,48 & 1 & 0 & 0 & 0 \\
\hline $\begin{array}{l}\text { Trib. Bell Creek } \\
\text { (TBC_LRM) }\end{array}$ & $\begin{array}{c}\text { Bell Meadow-Bear } \\
\text { Lake }\end{array}$ & $38.1580,-119.9569$ & 1932 & 2016 & 14 & 6,6 & 72,63 & 0 & 0 & 0 & 0 \\
\hline \multirow[t]{2}{*}{$\begin{array}{c}\text { Trib.1 NF Mokelumne } \\
\text { River(TNFMOKE_BCG) }\end{array}$} & Highland Lakes & $38.5340,-119.8197$ & 2399 & 2014 & 9 & 2,2 & 216,216 & 2 & 3 & 2 & 2 \\
\hline & & Total violations & & & & & & 14 & 14 & 13 & 13 \\
\hline
\end{tabular}

-, no data. (a) State recreational water contact threshold for fecal coliform (FC) is at least 5 samples within a given 30-day period during which a geometric mean of $200 \mathrm{cfu} / 100 \mathrm{~mL}$ cannot be exceeded [8]. (b) State recreational water contact threshold for fecal coliform (FC) is at least 5 samples within a given 30 -day period during which no more than $10 \%$ of samples may exceed $400 \mathrm{cfu} / 100 \mathrm{~mL}$ [8]. (c) Federal recreational water contact threshold for E. coli (EC) is at least 5 samples within a given 30-day period during which a geometric mean of $126 \mathrm{cfu} / 100 \mathrm{~mL}$ cannot be exceeded [9]. (d) Federal recreational water contact threshold for E. coli (EC) is at least 5 samples within a given 30 -day period during which no more than $10 \%$ of samples may exceed $235 \mathrm{cfu} / 100 \mathrm{~mL}$ [9]. (e) Federal recreational water contact threshold for E. coli (EC) is at least 5 samples within a given 30 -day period during which a geometric mean of 126 $\mathrm{cfu} / 100 \mathrm{~mL}$ cannot be exceeded [7]. (f) Federal recreational water contact threshold for E. coli (EC) is at least 5 samples within a given 30 -day period during which no more than $10 \%$ of samples may exceed $410 \mathrm{cfu} / 100 \mathrm{~mL}$ [7]. (g) Federal recreational water contact threshold for E. coli (EC) is at least $5 \mathrm{samples}$ within a given 30-day period during which a geometric mean of $126 \mathrm{cfu} / 100 \mathrm{~mL}$ cannot be exceeded [7]. (h) Federal recreational water contact threshold for E. coli (EC) is at least 5 samples within a given 30-day period during which no more than $10 \%$ of samples may exceed $310 \mathrm{cfu} / 100 \mathrm{~mL}$ [7]. 

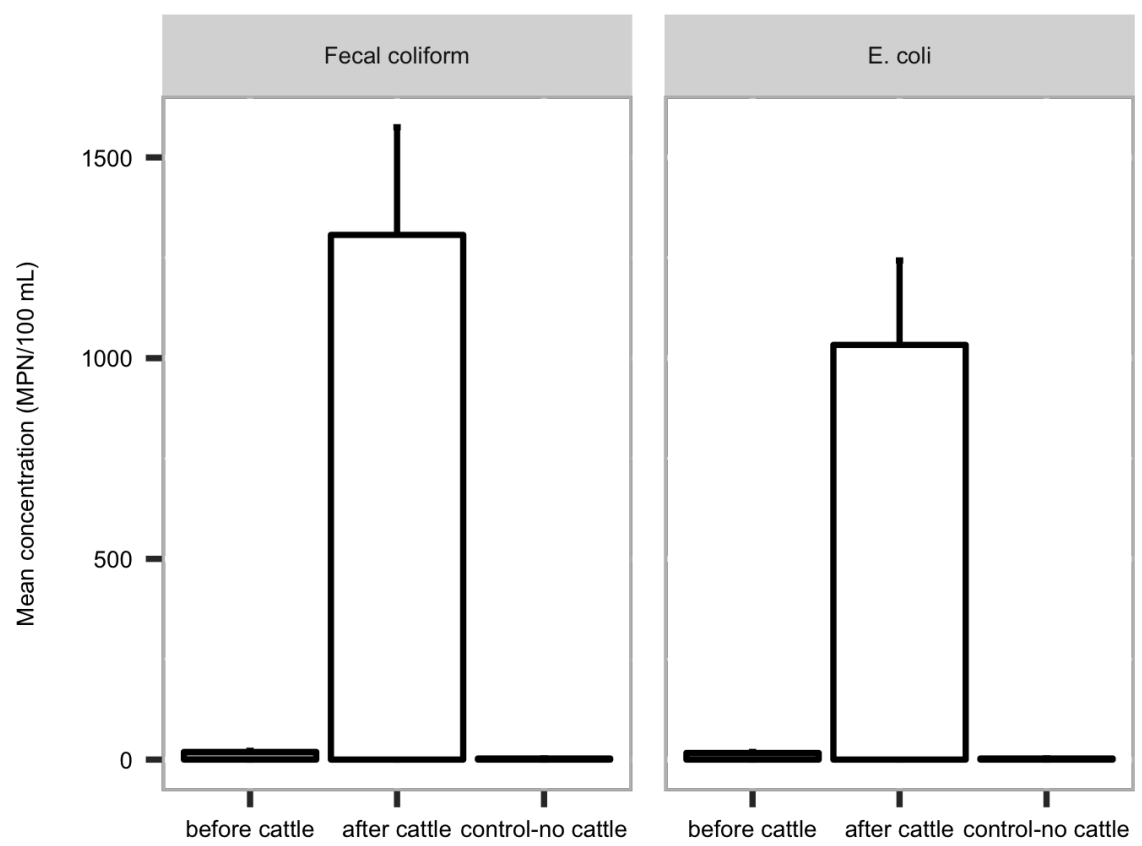

Figure 2. Mean fecal coliform (left graph) and Escherichia coli (right grahp) concentrations (MPN/100 mL) across 14 sites sampled between 2012 and 2016 within grazing areas on the Stanislaus National Forest, CA, just prior to cattle being released onto the forest ("before cattle"), after cattle were released onto the forest ("after cattle"), and also concentrations at the control site where no cattle are permitted during any time period ("control-no cattle"). Error bars denote standard error.

documented at Bell Cr. were detected eight to 11 weeks after cattle were released onto the forest.

The presence of cattle was an important indicator of fecal coliform concentrations $\left(\mathrm{F}_{1,210}=105, \mathrm{p}<0.001\right)$. Similar results were found for E. coli $\left(\mathrm{F}_{1,210}=85.5\right.$, $\mathrm{p}<0.001)$. Mean fecal coliform and $E$. coli concentrations were on orders of magnitude higher once cattle were on the forest compared to concentrations before cattle were on the forest, and compared to the control site (Figure 2).

Evidence of recent cattle-related disturbance was also an important predictor variable for fecal coliform $\left(\mathrm{F}_{1,210}=14.8, \mathrm{p}=0.002\right)$ and E. coli $\left(\mathrm{F}_{1,210}=15.9, \mathrm{p}<\right.$ 0.001 ). Mean ( \pm 2 standard deviation) fecal coliform and $E$. coli concentrations were on orders of magnitude higher with the presence of recent cattle-related disturbance (FC, $2041 \pm 5026 \mathrm{MPN} / 100 \mathrm{~mL}$; EC, $1554 \pm 372 \mathrm{MPN} / 100 \mathrm{~mL}$ ) compared to concentrations when there was no evidence of recent cattle-related disturbance (FC, $299 \pm 1723 \mathrm{MPN} / 100 \mathrm{~mL}$ EC, $259 \pm 1607 \mathrm{MPN} / 100 \mathrm{~mL}$ ) at the time of sampling.

Sampling week was also an important indicator of fecal coliform $\left(\mathrm{F}_{11,210}=6.8\right.$, $\mathrm{p}<0.001)$ and $E$. coli $\left(\mathrm{F}_{11,210}=7.1, \mathrm{p}<0.001\right)$. Mean $( \pm 2$ standard deviation $)$ concentrations were highest during the $11^{\text {th }}$ week after cattle were released onto the forest at one site (Bell Cr.: FC, 18,500 \pm 16, 263 MPN/100 mL; EC, 11,000 \pm $8485 \mathrm{MPN} / 100 \mathrm{~mL}$ ), but all other sites had highest mean concentrations during the $2^{\text {nd }}$ week after cattle were released onto the forest (FC, $402 \pm 778 \mathrm{MPN} / 100$ 
$\mathrm{mL}$; EC, $343 \pm 652 \mathrm{MPN} / 100 \mathrm{~mL})$.

Fecal coliform and E. coli concentrations at the control site located on Bourland Creek (in the Bourland Research Natural Area where no livestock grazing is authorized) were consistently $<4 \mathrm{MPN} / 100 \mathrm{~mL}$ during sampling in 2012, with no violations of state or federal standards (Table 1 ).

\section{Discussion}

This study assessed levels of stream pathogenic indicator bacteria (fecal coliform and $E$. coli) concentrations in 14 forest streams located within grazing areas and 1 control site (no cattle present) within a single national forest (Stanislaus $\mathrm{Na}$ tional Forest, STF) in the Sierra Nevada, California from 2012-2016. Results demonstrate that all 194 violations were documented when cattle were on the forest. In addition, the results of this study demonstrate that fecal coliform and $E$. coli were detected at orders of magnitude higher once cattle arrived on the forest than during the period before cattle were on the forest. Furthermore, evidence of recent cattle-related disturbances (e.g., manure, stream bank chiseling, sloughing, pocking) during sampling events, and sampling week were also important predictors of fecal coliform and E. coli. These findings suggest that cattle, as currently permitted and regulated on national forest lands managed for livestock grazing, are linked to increased stream pathogenic bacteria levels, and that stream pathogenic bacteria pollution is prevalent and widespread across the forest.

Numerous studies have demonstrated that stream pathogenic bacteria pollution is strongly associated with cattle presence in the Sierra Nevada region [10] [11] [13] [15] [16] [17]. Several additional studies have demonstrated similar relationships between increased pathogenic bacteria concentrations in surface waters and cattle in other regions of the US [14] [18] and also internationally [26] [27] [28]. [11] found that $96 \%$ of cattle-occupied stream sites sampled in the Sierra Nevada were positive for fecal bacteria. [15] found that cattle presence was the strongest predictor variable for $E$. coli concentrations based on over 700 samples from 111 sites in the eastern Sierra Nevada. Fecal coliform, total coliform, and $E$. coli concentrations were statistically different in grazed areas where livestock had unrestricted access to the riparian corridor compared to areas where livestock were excluded from the riparian zone (Wilkes et al., 2011). [14] documented a 12-fold increase in fecal coliform levels after cattle were brought onto grazing allotments.

In this study, $57 \%$ of stream sites sampled in grazing areas within the STF had at least one violation of either state regulatory standard for fecal coliform or federal regulatory standard for E. coli. [16] also found numerous violations of state regulatory standards for fecal coliform in streams near grazing areas on the STF. These findings demonstrate that stream pathogenic indicator bacteria levels may also be in exceedance of both state and federal water quality standards in additional sites with livestock presence across the STF. However, four sites in grazing 
areas on the STF had no violations of state or federal standards (see Table 1 and et al.): one of those sites had no cattle present or visual evidence of cattle-related disturbance during sampling events (Eagle Creek), and three of the sites had cattle present or there was evidence of cattle-related disturbance during sampling events (Herring Creek, NF Mokelumne River, and a tributary to NF Mokelumne River). Therefore, additional assessment of stream water quality across other national forests with widespread livestock presence would be valuable to provide both forest managers and the public further insight into the degree of stream pollution associated with the presence of livestock, especially in areas of the forest heavily used simultaneously by livestock and recreational forest visitors.

Comparing fecal coliform and E. coli concentrations immediately before cattle were released onto the forest to concentrations documented during the weeks after cattle were on the forest allowed a direct comparison of stream bacteria conditions with and without the presence of cattle. Although most sites had concentrations in violations of state or federal standards within the first five weeks after the introduction of cattle onto the forest, there was one site (Bell Creek) where increased bacteria concentrations were not observed until eight to 11 weeks after cattle were released onto the forest. This is due to the fact that the site on Bell Creek is located adjacent to a gathering meadow, and concentrated cattle use in the area is not prevalent until the last two to four weeks of the permitted grazing season. At the other sites, cattle were usually observed in proximity to the sites within the first two months after cattle were released onto the forest. These results demonstrate further that the presence of cattle in an area is consistent with measurable increases in fecal coliform and E. coli concentrations.

Natural temporal variation in stream conditions (e.g., stream flow, water temperature, algal biomass, stream substrate composition) can affect stream bacteria concentrations separate from forest activities such as livestock grazing [29]. Temporal variation in livestock management practices (e.g., livestock densities, herding intensities, grazing utilization) may also contribute to differences detected in stream bacteria concentrations, however the authors of this study are unaware of any research that has quantified the effects of varying grazing management practices on in stream pathogenic indicator bacteria concentrations. Future research could attempt to quantify livestock use in the vicinity of sampling sites (e.g., manure densities, grazing utilization) in addition to in stream conditions to better understand temporal variation at individual streams sites and also to better understand the relationship between livestock densities and pathogenic indicator bacteria concentrations. This kind of information may help to better explain the sites in this study that had evidence of cattle presence, but no measured violations of state or federal standards for indicator bacteria.

Although many forms of microorganisms, including bacteria, are critical components of aquatic habitats, some forms of in stream bacteria, viruses, and other microorganisms originate from animal fecal pollution (e.g., Cryptospori- 
dium, Giardia, E. coli 0157:H7, Salmonella) and can cause human illness. In addition to cattle, other livestock (e.g., sheep), pack stock, wildlife, and humans can contribute fecal material to forest streams and increase in stream pathogenic bacteria concentrations. The presence of pack stock in the vicinity of streams has shown to be related to increased concentrations of stream bacteria [10] [11]. Recreational activities (e.g., backpackers, day hikers) can also be associated with increased stream bacterial levels [11] [19]. Although this study did not focus on other potential contributors to stream pathogenic bacteria levels (e.g., humans, wildlife, pack stock) at the stream sites within grazing areas, the pathogenic indicator bacteria results from the control site on Bourland Creek, where cattle were excluded from accessing the stream at and upstream of the sampling site, demonstrates that bacteria contributions from sources other than cattle (e.g., wildlife, pack stock, humans) were negligible (fecal coliform, $<4 \mathrm{MPN} / 100 \mathrm{~mL}$; E. coli $<4 \mathrm{MPN} / 100 \mathrm{~mL}$ ). Future research could employ genetic techniques (e.g., microbial source tracking) to determine relative contributions of different sources of fecal material to stream pollution levels [30].

Livestock management activities near streams and other aquatic areas can not only increase levels of pathogenic bacteria, but can also destabilize streambanks, lead to soil compaction, increase stream turbidity, and reduce vegetative cover [4] [5]. In addition, changing climatic conditions, affecting temperature and precipitation in regions like the western U.S., may intensify the impacts of current livestock management activities on ecosystem function and health [31]. Practices that could minimize these impacts to forest streams include active herding, livestock exclusion fencing, animal crossings, or off stream water sources. These practices could minimize the duration and densities of cattle presence in and adjacent to forest streams and ultimately improve stream conditions [32], and may reduce concentrations of $E$. coli in streams [33]. In addition to altering livestock grazing management practices, increased water quality monitoring of high-use livestock areas in national forests would provide managers with additional insight into the extent of impacts of prolonged or concentrated presence of cattle near streams and the relationship of livestock to violations of water quality standards, demonstrated in this study and in others [16].

Due to the potential for health risk to forest visitors, there is a critical need to understand the implications of livestock grazing management in national forests to water quality. Since there are many activities occurring on national forests (e.g., livestock grazing, logging, pack stock use, recreation, and use of and maintenance of roads), those combined activities pose a challenge for managers and researchers to be able to discern the most significant sources of ecosystem degradation and associated risks to human health. However, the results of this study demonstrate a clear relationship between livestock presence and in stream bacteria pollution. Since national forests are meant to be multiple-use landscapes, it is imperative that forest managers have a clear understanding of the implications of forest activities to aquatic ecosystems in order to better protect 
the public from water-borne illness as recreational uses increase on national forest lands.

\section{Conclusion}

This study demonstrates that water quality sampling of numerous streams within a single national forest in the Sierra Nevada consistently had elevated concentrations of pathogenic indicator bacteria and that many of these sites were in violation of state and federal standards for recreational water contact. These results indicate the need for increased enforcement of water quality standards where livestock graze national forest lands and the need to consider alternative range management practices to better protect water quality and human health.

\section{Acknowledgements}

This research was funded by the Central Sierra Environmental Resource Center (CSERC) and donations from center members and supporters. This research was also funded in part by the Rose Foundation for Communities and the Environment (Oakland, CA).

\section{References}

[1] United State Department of Agriculture (USDA) (2017) National Visitor Use Monitoring. Natural Resource Manager. https://apps.fs.usda.gov/nfs/nrm/nvum/results/

[2] Government Accountability Office (GAO) (2005) Livestock Grazing, Federal Expenditures and Receipts Vary, Depending on the Agency and the Purpose of the Fee Charged. GAO-05-869. http://www.gao.gov/new.items/d05869.pdf

[3] Kauffman, J.B. and Krueger, W.C. (1984) Livestock Impacts on Riparian Ecosystems and Streamside Management Implications... A Review. Journal of Range Management, 37, 430-438. https://doi.org/10.2307/3899631

[4] Fleisncher, T.L. (1994) Ecological Costs of Livestock Grazing in Western North America. Conservation Biology, 8, 629-644. https://doi.org/10.1046/j.1523-1739.1994.08030629.x

[5] Belsky, A.J., Matzke, A. and Uselman, S. (1999) Survey of Livestock Influences on Stream and Riparian Ecosystems in the Western United States. Journal of Soil and Water Conservation, 54, 419-431.

[6] White, E., Bowker, J.M., Askew, A.E., Langner, L.L., Arnold, J.R. and English, D.B. (2016) Federal Outdoor Recreation Trends: Effects on Economic Opportunities. Report Prepared for National Center for Natural Resources Economic Research, Working Paper Number 1.

[7] United States Environmental Protection Agency (USEPA) (2012) Recreational Water Quality Criteria. US Environmental Protection Agency Office of Water Regulations and Standards, Washington DC, 1-73.

[8] California Regional Water Quality Control Board (CRWQCB) (2016) Water Quality Control Plan for the Sacramento and San Joaquin River Basins, 4th Edition, California Regional Water Quality Control Board, Central Valley Region, Sacramento, California.

[9] United States Environmental Protection Agency (USEPA) (1986) Quality Criteria for Water: 1986. US Environmental Protection Agency Office of Water Regulations 
and Standards, Washington DC, 1-477.

[10] Derlet, R.W. and Carlson, J.R. (2006) Coliform Bacteria in Sierra Nevada Wilderness Lakes and Streams: What Is the Impact of Backpackers, Pack Animals, and Cattle? Wilderness and Environmental Medicine, 17, 15-20. https://doi.org/10.1580/PR05-05.1

[11] Derlet, R.W., Ger, K.A., Richards, J.R. and Carlson, J.R. (2008) Risk Factors for Coliform Bacteria in Backcountry Lakes and Streams in the Sierra Nevada Mountains: A 5-Year Study. Wilderness and Environmental Medicine, 19, 82-90. https://doi.org/10.1580/07-WEME-OR-1511.1

[12] Derlet, R.W., Richards, J.R. and Goldman, C.R. (2012a) Does Above-Normal Precipitation Reduce the Impact of Mountain Cattle Grazing on Watershed Algae and Bacteria? Water Quality Exposure and Health, 4, 105-112. https://doi.org/10.1007/s12403-012-0069-8

[13] Derlet, R.W., Richards, J.R., Tanaka, L.L., Hayden, C., Ger, K.A. and Goldman, C.R. (2012b) Impact of Summer Cattle Grazing on the Sierra Nevada Watershed: Aquatic Algae and Bacteria. Journal of Environmental and Public Health, 2012, 1-7. https://doi.org/10.1155/2012/760108

[14] Genzoli, L., Robinson, C. and Asarian, J.E. (2015) Patterns of Fecal Indicator Bacteria in the Scott River Watershed, 2007-2014. Prepared by Kier Associates and Quartz Valley Indian Reservation. Prepared for the Quartz Valley Indian Reservation, Fort Jones, 1-47.

[15] Knapp, R. and Nelson, C. (2015) Assessment of Bacterial Water Quality in the Lahontan Region. Final Report, State Water Resource Control Board Contract No. 12-067-160, 1-73.

[16] Myers, L. and Kane, J. (2011) The Impact of Summer Cattle Grazing on Surface Water Quality in High Elevation Mountain Meadows. Water Quality Exposure and Health, 3, 51-62. https://doi.org/10.1007/s12403-011-0043-x

[17] Myers, L. and Whited, B. (2012) The Impact of Cattle Grazing in High Elevation Sierra Nevada Mountain Meadows over Widely Variable Annual Climatic Conditions. Journal of Environmental Protection, 3, 823-837. https://doi.org/10.4236/jep.2012.328097

[18] Wilkes, G., Edge, T.A., Gannon, V.P.J., Jokinen, C., Lyautey, E., Neumann, N.F., Ruecker, N., Scott, A., Sunohara, M., Topp, E. and Lapen, D.R. (2011) Associations among Pathogenic Bacteria, Parasites, and Environmental and Land Use Factors in Multiple Mixed-Use Watersheds. Water Research, 45, 5807-5825.

[19] Roche, L.M., Kromschroeder, L., Atwill, E.R., Dahlgren, R.A. and Tate, K.W. (2013) Water Quality Conditions Associated with Cattle Grazing and Recreation on $\mathrm{Na}$ tional Forest Lands. PLoS ONE, 8, e68127. https://doi.org/10.1371/journal.pone.0068127

[20] Ahearn, D.S., Sheibley, R.W., Dahlgren, R.A., Anderson, M., Johnson, J. and Tate, K.W. (2005) Land Use and Land Cover Influence on Water Quality in the Last Free-Flowing River Draining the Western Sierra Nevada, California. Journal of Hydrology, 313, 234-247.

[21] Roche, L.M., Allen-Diaz, B., Eastburn, D.J. and Tate, K.W. (2012) Cattle Grazing and Yosemite Toad (Bufocanorus Camp) Breeding Habitat in Sierra Nevada Meadows. Rangeland Ecology Management, 65, 56-65. https://doi.org/10.2111/REM-D-11-00092.1

[22] United States Forest Service (2017) Stanislaus National Forest: About the Forest. https://www.fs.usda.gov/main/stanislaus/about-forest 
[23] Myers, L. (2010) Surface Water Ambient Monitoring Project in the Stanislaus National Forest Quality Assurance Project Plan (QAPP). Central Sierra Environmental Resource Center (CSERC), Twain Harte.

http://www.cserc.org/local-issues/water/testing-and-protecting-water-quality

[24] Fiske, M. (2016) Surface Water Ambient Monitoring Project in the Stanislaus National Forest Quality Assurance Project Plan (QAPP). Central Sierra Environmental Resource Center (CSERC), Twain Harte. http://www.cserc.org/local-issues/water/testing-and-protecting-water-quality

[25] American Public Health Association (APHA) (1998) Microbiological Examination. In: Clesceri, L.S., Ed., Standard Methods for the Examination of Water and Wastewater, 4th Edition, United Book Press, Baltimore, 1-140.

[26] Jamieson, R.C., Gordon, R.J., Tattrie, S.C. and Stratton, G.W. (2003) Sources and Persistence of Fecal Coliform Bacteria in a Rural Watershed. Water Quality Research Journal of Canada, 38, 33-47.

[27] Tanaro, J.D., Piaggio, M.C., Galli, L., Gasparovic, A.M., Procura, F., Molina, D.A., Vitón, M., Zolezzi, G. and Rivas, M. (2014) Prevalence of Escherichia coli O157: H7 in Surface Water near Cattle Feedlots. Foodborne Pathogens and Disease, 11, 960-965. https://doi.org/10.1089/fpd.2014.1770

[28] Wilcock, R.J., Monaghan, R.M., Thorrold, B.S., Meredith, A.S., Betteridge, K. and Duncan, M.J. (2007) Land-Water Interactions in Five Contrasting Dairying Catchments: Issues and Solutions. Land Use and Water Resources Research, 7, 2.1-2.10.

[29] Ward, A.K. (2007) Heterotrophic Bacteria. In: Hauer, R. and Lamberti, G.A., Eds., Methods in Stream Ecology, 2nd Edition, 293-309.

[30] Badgley, B. and Hagedorn, C. (2015) Microbial Source Tracking: Advances in Research and a Guide to Application in Advances. In: Younos, T. and Parece, T.E., Eds., Watershed Science and Assessment. The Handbook of Environmental Chemistry, Springer International Publishing, Switzerland, 267-288.

[31] Beschta, R.L., Donahue, D.L., DellaSala, D.A., Rhodes, J.J., Karr, J.R., O’Brien, M.H., Fleischner, T.L. and Williams, C.D. (2013) Adapting to Climate Change on Western Public Lands: Addressing the Ecological Effects of Domestic, Wild, and Feral Ungulates. Environmental Management, 51, 474-491. https://doi.org/10.1007/s00267-012-9964-9

[32] Tate, K.W. (2006) Confirmation of Riparian Friendly Grazing Project Results and Development of Achievable, Site Specific Reference Conditions for Grazed Riparian Areas. Final Report to USDA Sustainable Agricultural Research and Education Program.

[33] Bragina, L., Sherlock, O., van Rossum, A.J. and Jennings, E. (2017) Cattle Exclusion using Fencing Reduces Escherichia coli (E. coli) Level in Stream Sediment Reservoirs in Northeast Ireland. Agriculture, Ecosystems and Environment, 239, 349-358. 